\title{
Modelling of Two-stage ANaerobic
}

TREATING WAStEWATER FROM A

Molasses-Based Ethanol Distillerey

With the IWA ANAEROBIC Digestion

MODEL No.1

Kittikhun Taruyanon and Sarun Tejasen *

Department of Environmental Engineering, Faculty of Engineering,

Chulalongkorn University, Bangkok, Thailand 10330

E-mail : ake_104@yahoo.com,sarun.t@chula.ac.th*

\section{ABSTRACT}

The Objective of this paper is to present the application of the Modified ADM1 model to simulate the dynamic behaviour of a two-stage anaerobic treatment process treating the wastewater generated from the ethanol distillery process. The laboratory-scale process comprised an anaerobic continuous stirred tank reactor (CSTR) and an upflow anaerobic sludge blanket (UASB) connecting in series, was used to treat wastewater from the ethanol distillery process. The CSTR and UASB hydraulic retention times (HRT) were 12 and 70 hours, respectively. The model was developed based on ADM1 basic structure and implemented with the simulation software AQUASIM. The simulated results were compared with measured data obtained from using the laboratory-scale two-stage anaerobic treatment process to treat wastewater. The sensitivity analysis identified maximum specific uptake rate $\left(k_{m}\right)$ and half-saturation constant $\left(\mathrm{K}_{\mathrm{s}}\right)$ of acetate degrader and sulfate reducing bacteria as the kinetic parameters which highly affected the process behaviour, which were further estimated. The study concluded that the model could predict the dynamic behaviour of a two-stage anaerobic treatment process treating the ethanol distillery process wastewater with varying strength of influents with reasonable accuracy.

\section{KEYWORDS}

modelling, Two-stage anaerobic, ADM1, distillery, AQUASIM 


\section{Introduction}

Molasses-Based ethanol distillery is one of the industries generating the most polluted wastewater. The generated wastewater is both high strength and large in volume. The wastewater has high concentration of chemical oxygen demand (COD) and biochemical oxygen demand (BOD), low pH, odorous, blackish brown colour, and contains substances such as nitrogen, phosphorous, potassium, sulfate, chloride etc which would severely affect the environment if discharged directly. Since the ethanol distillery process wastewater is of high strength, the most suitable treatment process of interest is the anaerobic treatment process which is capable of handling high organic loading rate and low sludge production. Furthermore, the process has the positive net energy production in the form of biogas which can replace fossil fuel [1]. The anaerobic digestion process has two main biochemical stages; the acidogenesis and methanogenesis stages. Since acidogenic and methanogenic organisms require different kinetic parameters and optimum $\mathrm{pH}$ for growth, two reactors were used to create suitable environment for each group of organisms. Hence, the process is called two-stage anaerobic process. There are only a few studies available on the modelling of two-stage anaerobic process. The application of model will enable the study of the effect of operating variables on the performance of the two-stage anaerobic process, and can be used as a tool for the design, evaluation and operation of the system.

The anaerobic digestion model no.1 (ADM1) had been developed recently by an International Water Association (IWA) Task Group [1]. ADM1 comprises steps in biochemical and physico-chemical processes [2]. The stages in biochemical process include substrate disintegration, hydrolysis, acidogenesis, acetogenesis and methanogensis, respectively. This model takes into account seven bacterial groups. The steps in physico-chemical process include ion association / dissociation and gas-liquid transfer. The objectives of ADM1 development were to build a common platform for anaerobic process modelling and simulation, and to encourage the application in anaerobic research, development, operation and optimization. [1]. ADM1 has been widely used for dynamic simulation of different anaerobic treatment processes such as for black water wastewater [3], olive mill wastewater [4], chinese medicine wastewater [5], evaporator condensate from a sulphite pulp mill [6], organic waste and wasted activated sludge [7].

The application of ADM 1 with the simulation of two-stage anaerobic treatment process of ethanol distillery wastewater had not been undertaken before. The objective of this study was to apply ADM 1 to build a model to simulate the dynamic behaviour of a two-stage anaerobic treatment process treating ethanol distillery wastewater. The modified ADM 1 model was calibrated with the first set of data obtained from laboratory-scale CSTR and UASB reactors treating wastewater from ethanol distillery, and validated with the second set of data from the experiment.

\section{Materials and Methods}

\subsection{Experimental setup}

The laboratory-scale system used in the study comprised an anaerobic continuous stirred tank reactor (CSTR) and an upflow anaerobic sludge blanket (UASB) connecting in series (Figure1). The CSTR was maintained in the acidogenic condition and had the total liquid volume approximately $1.7 \mathrm{~L}$ with an internal diameter of $0.10 \mathrm{~m}$ and a water depth of $0.22 \mathrm{~m}$., an agitator was installed to provide mixing inside the reactor. The UASB was maintained in the methanogenic condition and had the total liquid volume approximately $10 \mathrm{~L}$ with an internal diameter of $0.08 \mathrm{~m}$ and a height of $1.50 \mathrm{~m}$. A three-phase separator was installed at the top of the reactor to separate gas from liquid and to prevent biomass washout. The CSTR and UASB hydraulic retention times (HRT) were 12 and 70 hours, respectively. The reactors operated at the ambient temperature 
Figure 1

Schematic diagram of two-stage anaerobic treatment process

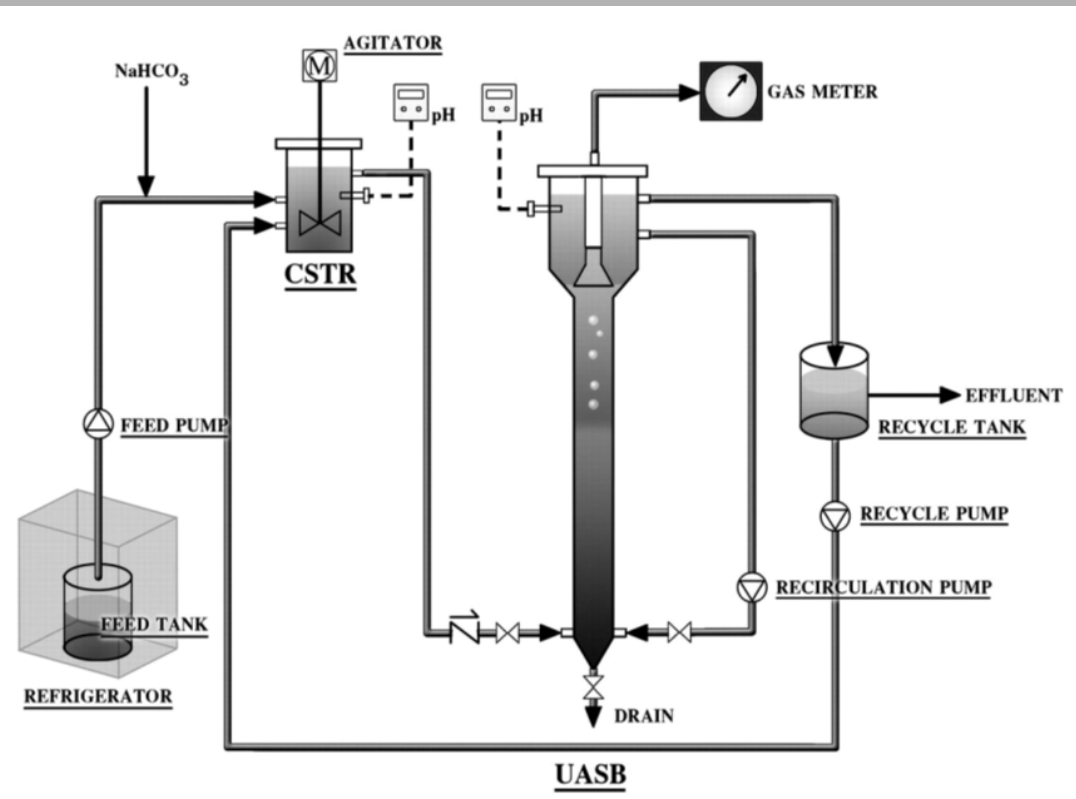

\subsection{Feed}

The wastewater was obtained from a molasses-based ethanol distillery in Thailand. The wastewater was diluted with tap water to obtain desired concentrations, and $\mathrm{pH}$ adjusted by adding $\mathrm{NaHCO}_{3}$ to maintain the $\mathrm{pH}$ in CSTR reactor at the controlled value. The experimental operating conditions were shown in Table 1. Conditions from data sets $\mathrm{C} 1-\mathrm{C} 3$ were used for model calibration, while conditions from data sets $\mathrm{V} 1-\mathrm{V} 5$ were used for model validation.

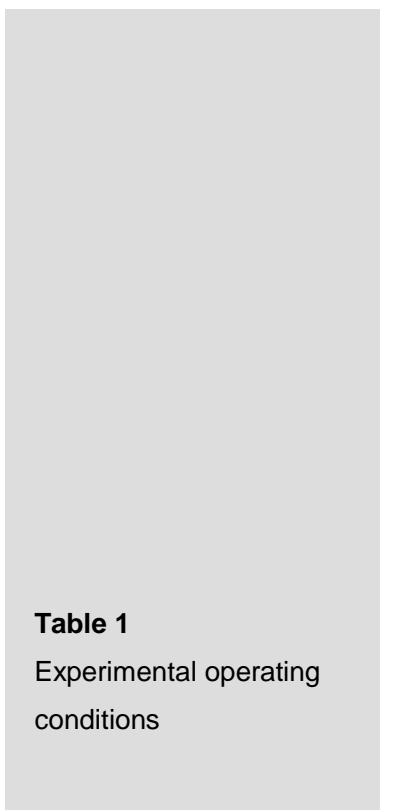

\begin{tabular}{ccccccc}
\hline $\begin{array}{c}\text { Data } \\
\text { set }\end{array}$ & $\begin{array}{c}\text { Feed flow } \\
\left(\mathbf{m}^{3} \cdot \mathbf{d}^{-1}\right)\end{array}$ & $\begin{array}{c}\text { Recycled flow } \\
\left(\mathbf{m}^{3} . \mathbf{d}^{-1}\right)\end{array}$ & $\begin{array}{c}\text { pH in } \\
\text { CSTR }\end{array}$ & $\begin{array}{c}\text { Influent COD } \\
\left(\mathbf{g} \cdot \mathbf{m}^{-3}\right)\end{array}$ & $\begin{array}{c}\text { Influent sulfate } \\
\left(\mathbf{g S} . \mathbf{m}^{-3}\right)\end{array}$ & $\begin{array}{c}\text { Organic load } \\
\left(\mathbf{k g C O D} \cdot \mathbf{m}^{-3}\right)\end{array}$ \\
\hline C1 & 0.0034 & - & 6.0 & 12,600 & 309 & 3.8 \\
C2 & 0.0034 & - & 6.0 & 23,250 & 346 & 7.0 \\
C3 & 0.0034 & - & 6.0 & 33,250 & 783 & 10.0 \\
\hline V1 & 0.0034 & 0.0034 & 5.5 & 6,650 & 221 & 4 \\
V2 & 0.0034 & 0.0034 & 5.5 & 13,300 & 311 & 6 \\
V3 & 0.0034 & 0.0034 & 5.5 & 19,950 & 510 & 8 \\
V4 & 0.0034 & 0.0034 & 5.5 & 26,600 & 617 & 4 \\
V5 & 0.0034 & 0.0034 & 5.5 & 13,300 & 312 & \\
\hline
\end{tabular}

\subsection{Sampling and analysis}

The effluent $\mathrm{pH}$ of CSTR and UASB, and biogas production rate were measured daily. Samples were collected three times per week and analysed for COD, volatile fatty acids (VFA) and alkalinity. Total suspended solids (TSS), volatile suspended solids (VSS), and sulfate were collected and analysed when steady state was achieved. All samplings and analyses of variables were in accordance with APHA-AWWA standard analytical procedures. 


\section{Mathematical Model}

\subsection{Model description}

Anaerobic digestion model no.1 (ADM1) was presented by the IWA Task Group for mathematical modelling of anaerobic digestion process. ADM 1 model consists of several steps such as disintegration, hydrolysis, acidogenesis, acetogenesis and methanogenesis steps. Disintegration and hydrolysis are non-biological extracellular solubilization step. Disintegration step will convert composite particulate substrate to inerts, particulate carbohydrates, proteins and lipids. The enzymatic hydrolysis which is the following step will convert particulate carbohydrates, proteins and lipids to monosaccharides, amino acids and long chain fatty acids (LCFA), respectively. Both disintegration and hydrolysis processes are described by the first order kinetics [2]. There are seven bacterial groups in the biochemical conversion step.

Monosaccharides and amino acid will be converted by two groups of acidogenic to mixed organic acids, hydrogen and carbon dioxide. Subsequently, LCFA, butyrate and valerate, and propionate will be converted by three groups of acetogenic to acetate, hydrogen and carbon dioxide. Hydrogen and acetate generated by steps described will be used by hydrogen-utilising methanogenic group and aceticlastic methanogenic group, respectively. Every step of intracellular biochemical reactions is described by substrate-based uptake Monod-type kinetics. Death of biomass is described by the first order kinetics [2]. The dead biomass is maintained in the system as composite particulates. Inhibition functions include $\mathrm{pH}$ (all bacterial groups), hydrogen (acetogenic groups) and free ammonia (aceticlastic methanogenic group) [1]. Mechanisms describing physico-chemical processes are acid-base reactions for identifying hydrogen ions concentration, free ammonia and carbon dioxide and non-equilibrium liquid-gas transfer.

The ethanol distillery wastewater has high concentration of sulfate, however, the ADM1 does not include sulfate reduction simulation [1]. Therefore, the construction of ethanol distillery wastewater simulation model in this study needed to include an extension to allow for sulfate reduction within the biochemical and physico-chemical structures and kinetics of ADM1 model. Previous study shows that when the S:COD ratio is less than $0.1 \mathrm{gSgCOD}^{-1}$, sulfate reduction will first use only the existing hydrogen in the system [8]. In this study, the S:COD ratio was less than $0.033 \mathrm{gSgCOD}^{-1}$. Therefore, the study had added an extension to the ADM1 for sulfate reduction using a method recommended by Batstone et al. [1], [8]. This method is to assess sulfate reduction by oxidation of available hydrogen. The matrix of this extension is shown in Table 2 and Table 3. The physico-chemical process required this extension to describe $\mathrm{H}_{2} \mathrm{~S} / \mathrm{HS}$ acid-base equilibrium, $\mathrm{H}_{2} \mathrm{~S}$ stripping and the effect of $\mathrm{SO}_{4}^{2-}$ ion on the charge balance. 
Table 2

Modified ADM 1 for soluble component
Biochemical rate coefficients $\left(v_{i, j}\right)$ and kinetic equations $\left(\rho_{j}\right)$ for soluble components of Modified ADM1

\begin{tabular}{|c|c|c|c|c|c|c|c|c|c|c|c|c|c|}
\hline $\begin{array}{l}\text { Component }>\mid \\
\text { I Process } \bigvee\end{array}$ & $\begin{array}{c}1 \\
\mathrm{~S}_{\mathrm{su}}\end{array}$ & $\begin{array}{l}5 \\
s_{\mathrm{bu}}\end{array}$ & $\begin{array}{l}6 \\
s_{\mathrm{pro}}\end{array}$ & $\begin{array}{l}7 \\
S_{\mathrm{ac}}\end{array}$ & $\begin{array}{l}8 \\
S_{+2}\end{array}$ & $\begin{array}{l}8 a \\
S_{\text {Hras }}\end{array}$ & $\begin{array}{l}8 b \\
\text { Strs. }\end{array}$ & $\begin{array}{l}9 \\
S_{\mathrm{ctum}}\end{array}$ & $\begin{array}{l}10 \\
S_{\mathrm{co2} 2}\end{array}$ & $\begin{array}{c}\text { 10a } \\
\text { SHcos. }\end{array}$ & $\begin{array}{l}11 \\
s_{\mathrm{W}}\end{array}$ & $\begin{array}{l}12 \\
s_{1}\end{array}$ & $\begin{array}{l}12 a \\
S_{s o 4}\end{array}$ \\
\hline 1 Disintegration & 1 & & & & & & & & & & & & \\
\hline $\begin{array}{l}2 \text { Hydrolysis } \\
\text { carbohydrate }\end{array}$ & -1 & $\left(1-Y_{w}\right) f_{\text {tux }}$ & $\left(1-Y_{y_{N}}\right)_{+\infty}^{+\infty}$ & $\left(1-Y_{s u s}\right) f_{\operatorname{san} a}$ & $\left(1-Y_{\gamma_{u s}}\right)_{f_{2,2, \alpha}}$ & & & & $-\sum_{i=1,12=24} c V_{1,5}$ & & $-\left(Y_{x y}\right) N_{\text {ane }}$ & & \\
\hline $\begin{array}{l}5 \text { Uptake of } \\
\text { sugars }\end{array}$ & & -1 & & $\left(1-Y_{c t}\right) 0.8$ & $\left(1-Y_{c 4}\right) 0.2$ & & & & & & $-\left(Y_{c a t}\right) N_{a x}$ & & \\
\hline $\begin{array}{l}9 \text { Uptake of } \\
\text { butyrate }\end{array}$ & & & -1 & $\left(1-Y_{p o s}\right) 0.57$ & $\left(1-Y_{p e}\right) 0.43$ & & & & 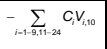 & & $-\left(Y_{\left.y_{0}\right)}\right) N_{\infty}$ & & \\
\hline $\begin{array}{c}10 \text { Uptake of } \\
\text { Propionate }\end{array}$ & & & & -1 & & & & $\left(1-Y_{\mathrm{ra}}\right)$ & 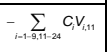 & & $-\left(Y_{x a s}\right) N_{\text {ous }}$ & & \\
\hline $\begin{array}{c}11 \text { Uptake of } \\
\text { Acetate }\end{array}$ & & & & & -1 & & & $\left(1-Y_{\left.r_{1}\right)}\right)$ & $-\sum_{i=1,1,-24} c V_{t, 12}$ & & $-\left(Y_{12}\right) N_{\text {axe }}$ & & \\
\hline $\begin{array}{c}12 \text { Uptake of } \\
\text { Hydrogen }\end{array}$ & & & & & -1 & $\left(1-Y_{\text {Sas }}\right) / 64$ & & & $-\left(Y_{S a)}\right) C_{X, 504}$ & & $-\left(Y_{x a s}\right) N_{x+\infty a d}$ & & $-\left(1-Y_{\text {sed }}\right) / 64$ \\
\hline $\begin{array}{l}\text { 12a Sulfate } \\
\text { Reduction }\end{array}$ & & & & & & & & & & & & & \\
\hline $\begin{array}{c}13 \text { Decay of } \\
\mathrm{X}_{\mathrm{su}}\end{array}$ & & & & & & & & & & & & & \\
\hline $\begin{array}{l}16 \text { Decay of } \\
\mathrm{x}_{c}\end{array}$ & & & & & & & & & & & & & \\
\hline $\begin{array}{l}17 \text { Decay of } \\
\mathbf{X}_{\text {pro }}\end{array}$ & & & & & & & & & & & & & \\
\hline $\begin{array}{c}18 \text { Decay of } \\
\mathrm{X}_{\mathrm{ac}}\end{array}$ & & & & & & & & & & & & & \\
\hline $\begin{array}{l}19 \text { Decay of } \\
\mathrm{X}_{\mathrm{n} 2}\end{array}$ & & & & & & & & & & & & & \\
\hline $\begin{array}{l}20 \text { Decay of } \\
\mathrm{X}_{\text {Sou }}\end{array}$ & & & & & & & & & & & & & \\
\hline & 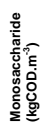 & 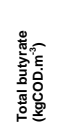 & 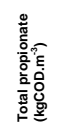 & 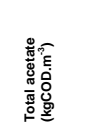 & 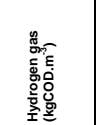 & 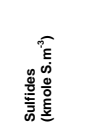 & 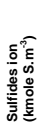 & 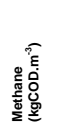 & 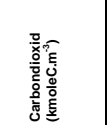 & 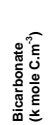 & 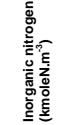 & 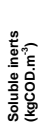 & 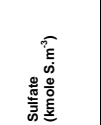 \\
\hline
\end{tabular}

Biochemical rate coefficients $\left(v_{i, j}\right)$ and kinetic equations $\left(\rho_{j}\right)$ for soluble components of Modified ADM1

\begin{tabular}{|c|c|c|c|c|c|c|c|c|c|c|c|c|}
\hline $\begin{array}{l}\text { Component } \\
{ }_{\text {Process }} \boldsymbol{V}\end{array}$ & $\begin{array}{l}13 \\
x_{e}\end{array}$ & $\begin{array}{l}14 \\
x_{\mathrm{ch}}\end{array}$ & $\begin{array}{l}17 \\
x_{s u}\end{array}$ & $\begin{array}{l}20 \\
x_{c 4}\end{array}$ & $\begin{array}{l}21 \\
x_{\mathrm{pro}}\end{array}$ & $\begin{array}{l}22 \\
x_{\mathrm{ac}}\end{array}$ & $\begin{array}{l}23 \\
X_{12}\end{array}$ & $\begin{array}{l}23 a \\
x_{s o s}\end{array}$ & $\begin{array}{l}24 \\
x_{1}\end{array}$ & $\begin{array}{l}25 \\
\mathrm{~S}_{\mathrm{CAr}}\end{array}$ & $\begin{array}{l}26 \\
\mathrm{~s}_{\mathrm{An}}\end{array}$ & 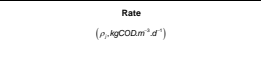 \\
\hline 1 Disintegration & 1 & $t_{\text {tora }}$ & & & & & & & $t_{\text {t.x }}$ & & & $k_{\mathrm{ds}} X_{\mathrm{c}}$ \\
\hline $\begin{array}{l}2 \text { Hydrolysis } \\
\text { carbohydrate }\end{array}$ & & -1 & & & & & & & & & & $k_{n \rightarrow d x} x_{c h}$ \\
\hline $\begin{array}{l}5 \text { Uptake of } \\
\text { sugars }\end{array}$ & & & $r_{w}$ & & & & & & & & & 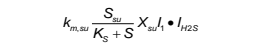 \\
\hline $\begin{array}{l}9 \text { Uptake of } \\
\text { butyrate }\end{array}$ & & & & $r_{c 4}$ & & & & & & & & 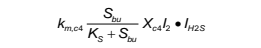 \\
\hline $\begin{array}{l}10 \text { Uptake of } \\
\text { Propionate }\end{array}$ & & & & & $r_{p o}$ & & & $\left(1-Y_{x x}\right)$ & & & & 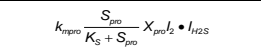 \\
\hline $\begin{array}{l}11 \text { Uptake of } \\
\text { Acetate }\end{array}$ & & & & & & $r_{\infty}$ & & $\left(1-Y_{1, n}\right)$ & & & & 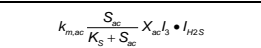 \\
\hline $\begin{array}{l}12 \text { Uptake of } \\
\text { Hydrogen }\end{array}$ & & & & & & & $Y_{n 2}$ & & & & & 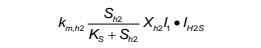 \\
\hline $\begin{array}{l}\text { 12a Sultate } \\
\text { Reduction }\end{array}$ & & & & & & & & & & & & 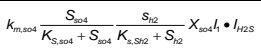 \\
\hline $\begin{array}{l}13 \text { Decay of } \\
\text { Xsu }\end{array}$ & 1 & & -1 & & & & & & & & & 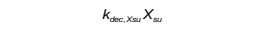 \\
\hline $\begin{array}{l}16 \text { Decay of } \\
\text { X }_{c 4}\end{array}$ & 1 & & & -1 & & & & & & & & 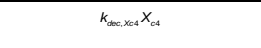 \\
\hline 17 Decay of & 1 & & & & -1 & & & & & & & 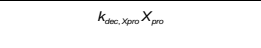 \\
\hline $\begin{array}{l}18 \text { Decay of } \\
\mathrm{x}_{\mathrm{ac}}\end{array}$ & 1 & & & & & -1 & & & & & & 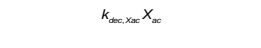 \\
\hline $\begin{array}{l}19 \text { Decay of } \\
\mathrm{X}_{\mathrm{n} 2}\end{array}$ & 1 & & & & & & -1 & & & & & $k_{\cos x x_{12} x_{12}}$ \\
\hline \multirow[t]{2}{*}{$\begin{array}{l}20 \text { Decay of } \\
\text { X }_{\text {sou }}\end{array}$} & 1 & & & & & & & -1 & & & & 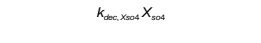 \\
\hline & 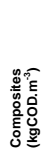 & 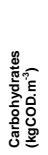 & 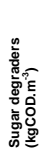 & 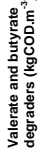 & 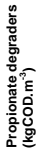 & 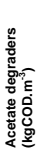 & 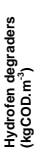 & 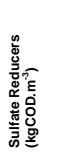 & 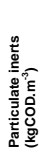 & 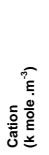 & 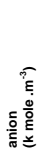 & \\
\hline
\end{tabular}

\subsection{Mass balance equations}

The CSTR was used to simulate the operation of an acid tank and UASB reactor as wastewater was recycled from UASB to the acid tank. Equations of soluble substrate and particulate substrate components in liquid state in the acid tank are shown in Equations (1) and (2), and those in the UASB are shown in Equations (3) and (4). 


$$
\begin{aligned}
& \frac{d S_{i, 1}}{d t}=\frac{Q_{i n}}{V_{\text {liq }, 1}}\left(S_{i, 1, i n}-S_{i, 1}\right)+\frac{Q_{\text {recy }}}{V_{\text {liq }, 1}}\left(S_{i, 2}-S_{i, 1}\right)+\sum_{j=1-20} \rho_{j} V_{i j} \\
& \frac{d X_{i, 1}}{d t}=\frac{Q_{i n}}{V_{\text {liq }, 1}}\left(X_{i, 1, i n}-X_{i, 1}\right)+\frac{Q_{\text {recy }}}{V_{\text {liq }, 1}}\left(X_{i, 2}-X_{i, 1}\right)+\sum_{j=1-20} \rho_{j} V_{i j} \\
& \frac{d S_{i, 2}}{d t}=\frac{\left(Q_{\text {in }}+Q_{\text {recy }}\right)}{V_{\text {liq, } 2}}\left(S_{i, 1}-S_{i, 2}\right)+\sum_{j=1-20} \rho_{j} V_{i j} \\
& \frac{d X_{i, 2}}{d t}=\frac{\left(Q_{\text {in }}+Q_{\text {recy }}\right)}{V_{\text {liq,2 }}} X_{i, 1}-\frac{X_{i, 2}}{S R T}+\sum_{j=1-20} \rho_{j} V_{i j} \\
& \text { SRT }=t_{\text {res }, X}+\frac{V_{\text {liq }, 2}}{\left(Q_{i n}+Q_{\text {recy }}\right)}
\end{aligned}
$$

When, $\mathrm{S}_{\mathrm{i}, 1}$ and $\mathrm{S}_{\mathrm{i}, 2}$ is concentration of soluble substrate component in the acid tank and UASB, respectively. $X_{i, 1}$ and $X_{i, 2}$ are concentration of paticulate substrate component or biomass in the acid tank and UASB, respectively. $V_{i q, 1}$ and $V_{i q, 2}$ are liquid reactor volume of the acid tank and UASB, respectively. $Q_{\text {in }}$ and $Q_{\text {recy }}$ are influent flow rate and recycle flow rate, respectively. $\sum_{\mathrm{j}=1-20} \rho_{\mathrm{j}} \mathrm{V}_{\mathrm{ij}}$ is the sum of specific kinetic rates for process $\mathrm{j}$ multiplied by the stoichiometric coeffeicients as shown in Table 2. and Table 3. $t_{\text {res }, x}$ is the solid residence time above hydraulic retention time.

\subsection{Model implementation}

The ADM1 was implemented with the simulation software AQUASIM. [10]-[11]. AQUASIM is a computer program for data analysis and simulation of aquatic systems. Apart from the simulation, AQUASIM also provided linear sensitivity analysis and parameter estimation tools. For this study the ADM1 was implemented as a differential and algebraic equation (DAE) and used an ideal CSTR compartment (Figure2) Ammonia and ammonium, volatile acids, hydroxide and hydrogen ions were implemented as equilibrium state variables. Other variables such as cations, anions, carbon dioxide and bicarbonate ion were implemented as dynamic state variables. All initial values of model parameters used values recommended by ADM1.

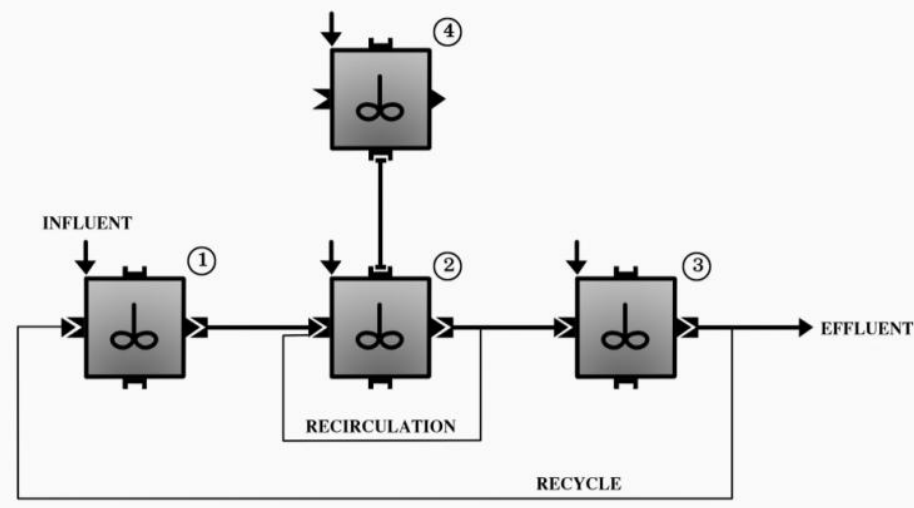
(1) CSTR
(2) UASB
(3) SETTLER
(4) HEADSPACE

Figure 2

Flow configuration of AQUASIM

\subsection{Sensitivity analysis and parameter estimation}

The sensitivity analysis allowed the identification of the most important parameters which needed to be adjusted during model calibration which depended on the 
sensitivity of parameters to the model output. The sensitivity analysis was performed by AQUASIM. AQUASIM is able to perform linear sensitivity analysis with respect to a set of selected parameters [11]. The calculated sensitivity functions allow the user to detect and interpret parameter identifiability problems [12]. The absolute-relative sensitivity function is used as shown in Equation (6) [13].

$$
\delta_{y, p}^{a, r}=P \frac{\partial y}{\partial p}
$$

Where $\delta_{y, p}^{a, r}$ is the sensitivity function, $y$ is an arbitrary variable calculated by AQUASIM and $p$ is a model parameter. The absolute-relative sensitivity function measures the absolute change in y for a $100 \%$ change in $p$ [13]. The positive sign of the sensitivity function indicates $y$ will increase when $p$ is increased. And the negative sign indicates $y$ will decrease when $p$ is increased.

AQUASIM is able to perform parameter estimations of the user-defined model using measured data. The parameters are estimated by using the weighted least squares method [12].

\section{Results and Discussions}

\subsection{Model salibration}

The sensitivity analysis identified parameters with high sensitivity that required parameter estimation. These parameters are $\mathrm{k}_{\mathrm{m}, \mathrm{ac}}, \mathrm{k}_{\mathrm{m}, \mathrm{so4}}, \mathrm{K}_{\mathrm{s}, \mathrm{ac}}, \mathrm{K}_{\mathrm{s}, \mathrm{so}}$ Their sensitivity functions of SCOD and sulfate concentration in UASB reactor are shown in Figure 3 and 4 The parameter estimation used values from ADM 1 as initial values for sensitive parameters, and used ADM 1 values as constants for parameters with low sensitivity. The simulations were performed in iteration with changing values for sensitive parameters until the simulated results were best fitted with the laboratory results. The model estimated parameter values are shown in Table 3. The comparisons between simulated and measured values for soluble chemical oxygen demand (SCOD), total volatile fatty acids (TVFA), gas flow rate and effluent $\mathrm{pH}$, after the model calibration are shown in Figure5.

Figure 3

Sensitivity functions (absolute-relative) of the SCOD in UASB to the model parameters $\left(k_{m, a c}, k_{m, 504}, K_{s, a c}, K_{s, 504}, K_{s, 512}\right.$ $\mathrm{K}_{\mathrm{In} 2 \mathrm{~s}}$ )
Sensitivity Functions for soluble COD

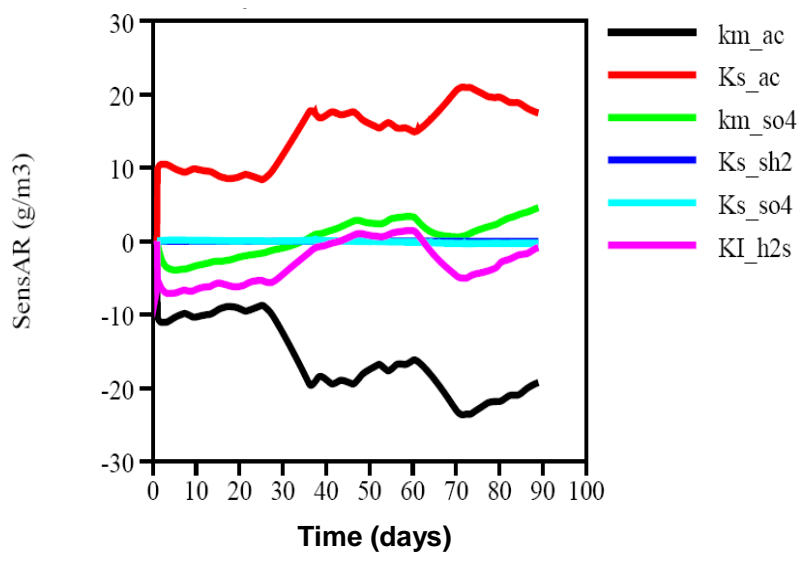




\section{Figure 4}

Sensitivity functions

(absolute-relative) of the sulfate in UASB to

the model

arameters

$\left(\mathrm{k}_{\mathrm{m}, \mathrm{SO} 4}, \mathrm{~K}_{\mathrm{S}, \mathrm{SO} 4}\right.$,

$\mathrm{K}_{\mathrm{S}, \mathrm{Sh} 2}, \mathrm{~K}_{\mathrm{l}, \mathrm{h} 2 \mathrm{~S}}$ )
Sensitivity functions for sulfate

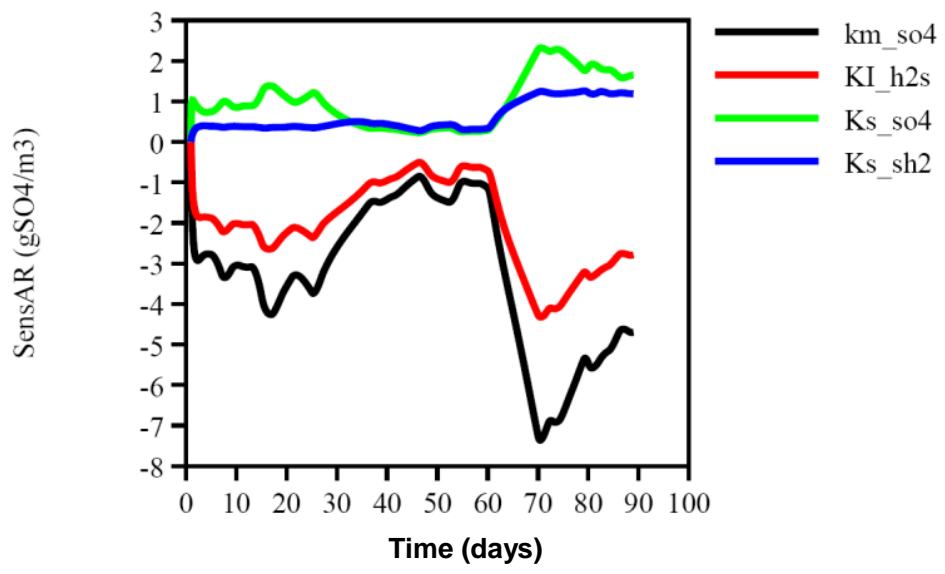

Table 3

Initial and estimated

values of kinetic

parameters

\begin{tabular}{ccccc}
\hline $\begin{array}{c}\text { Kinetic } \\
\text { Parameters }\end{array}$ & Description & $\begin{array}{c}\text { Initial } \\
\text { Values }\end{array}$ & $\begin{array}{c}\text { Estimated } \\
\text { Values }\end{array}$ & Units \\
\hline$K_{m, a c}$ & $\begin{array}{c}\text { Maximum uptake rate of } \\
\text { acetate degrader }\end{array}$ & 8 & 1.5216 & $\mathrm{~d}^{-1}$ \\
$K_{m, S O 4} \mathbb{F}$ & $\begin{array}{c}\text { Maximum uptake rate of } \\
\text { sulfate reducing bacteria } \\
\text { Half-saturation constant of } \\
K_{S, a c}\end{array}$ & 50 & 50.0786 & $\mathrm{~d}^{-1}$ \\
$K_{S, S O 4}$ & $\begin{array}{c}\text { Half-saturation constant of } \\
\text { sulfate }\end{array}$ & 0.1 & 150 & gCOD.m $\mathrm{m}^{-3}$ \\
\hline
\end{tabular}

Figure 5

Comparison between simulated results and experimental data after calibration:

a) Soluble COD

b) Total VFA

c) Sulfate

d) Gas flow rate

e) Effluent $\mathrm{pH}$

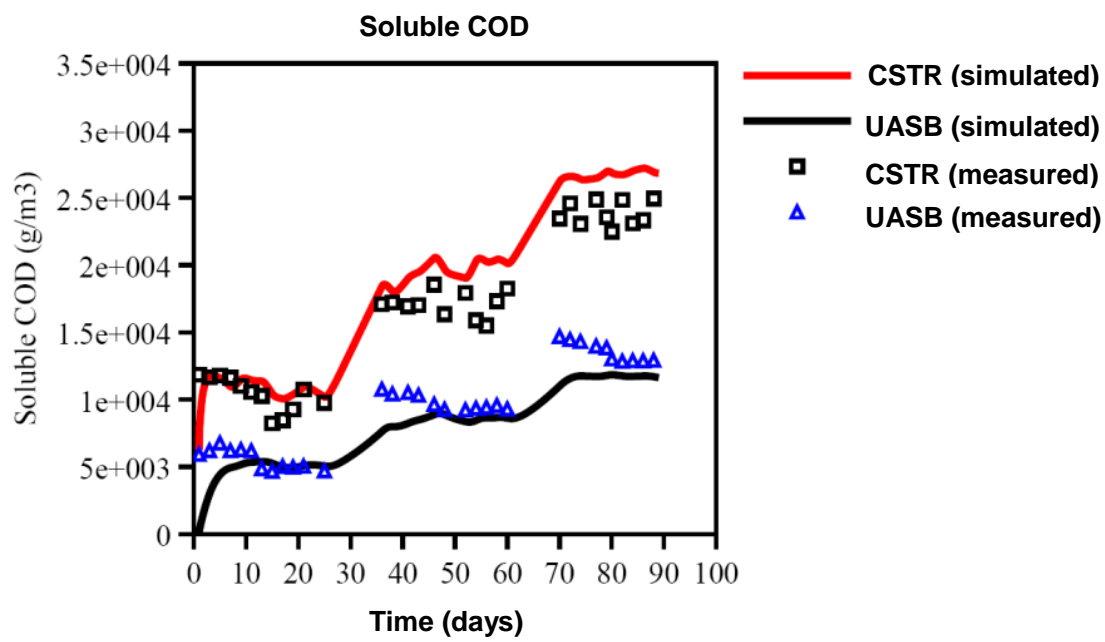

a) Soluble COD 


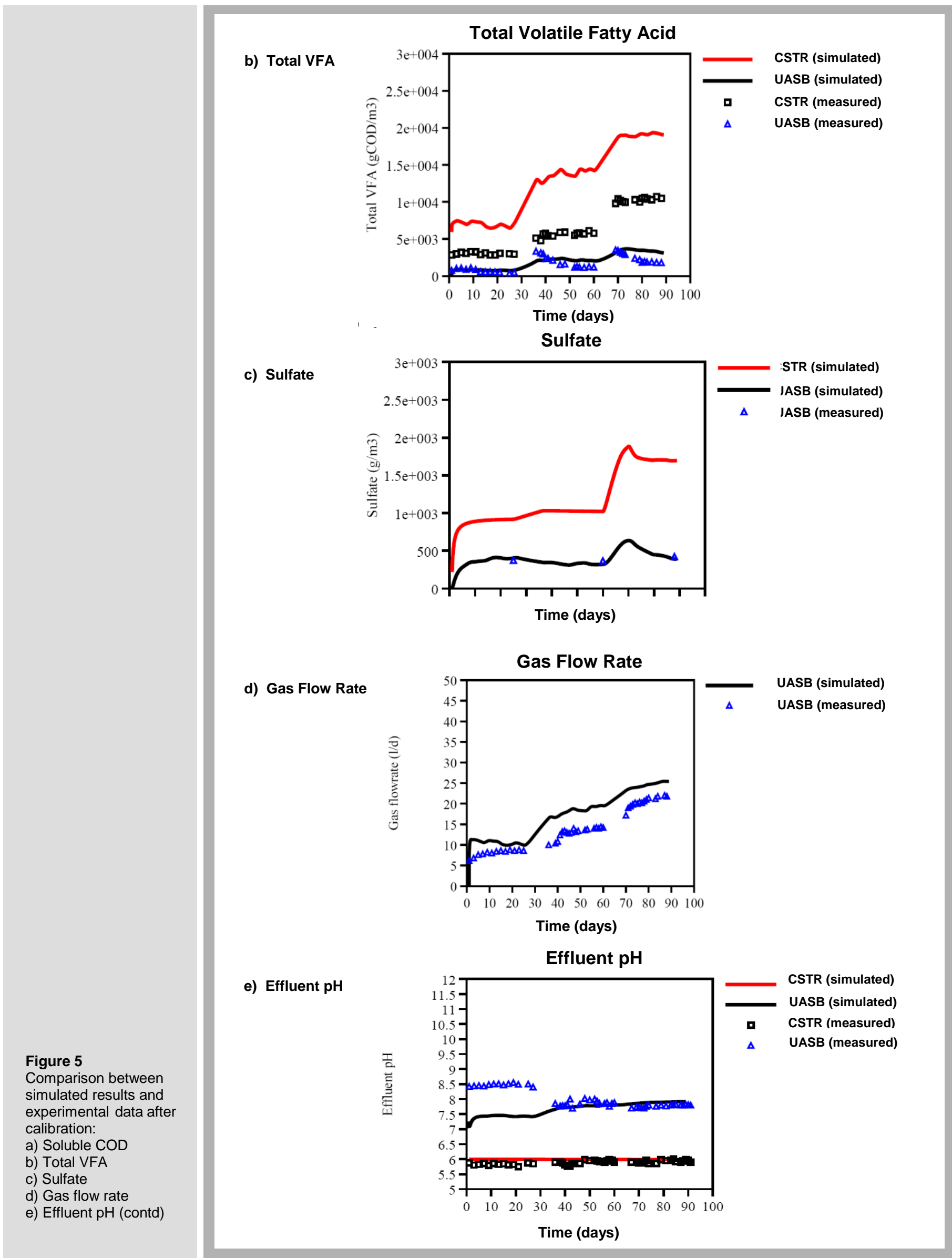

\subsection{Model validation}

The calibrated model was then validated with the second set of experimental data using the estimated parameters obtained from the calibration stage. The model validation results are as follows. 


\subsubsection{The simulation results of soluble chemical oxygen demand (SCOD)}

Figure 6(a) shows the simulated results and experimental data for SCOD. It can be observed that the model accurately predicted the SCOD in CSTR whilst closely predicted SCOD in UASB.

\subsubsection{The simulation results of total volatile fatty acid (TVFA)}

Figure 6(b) shows the simulated results and experimental data for TVFA. It can be observed that for CSTR the predicted TVFA were accurate. In the case of TVFA in UASB, the predicted values closely matched the experimental data.

\subsubsection{The simulation result of sulfate}

Figure 6(c) shows the simulated results and experimental data for sulfate. The model could accurately predict the sulfate in UASB.

\subsubsection{The simulation result of gas flow rate}

Figure 6(d) shows the simulated results and experimental data for gas flow rate. The predicted values were lower than the experimental data.

\subsubsection{The simulation result of effluent $\mathrm{pH}$}

Figure 6(e) shows the simulated results and experimental data for effluent $\mathrm{pH}$. The model accurately predicted the $\mathrm{pH}$ in CSTR effluent but the predicted $\mathrm{pH}$ in UASB effluent were lower than the experimental data.

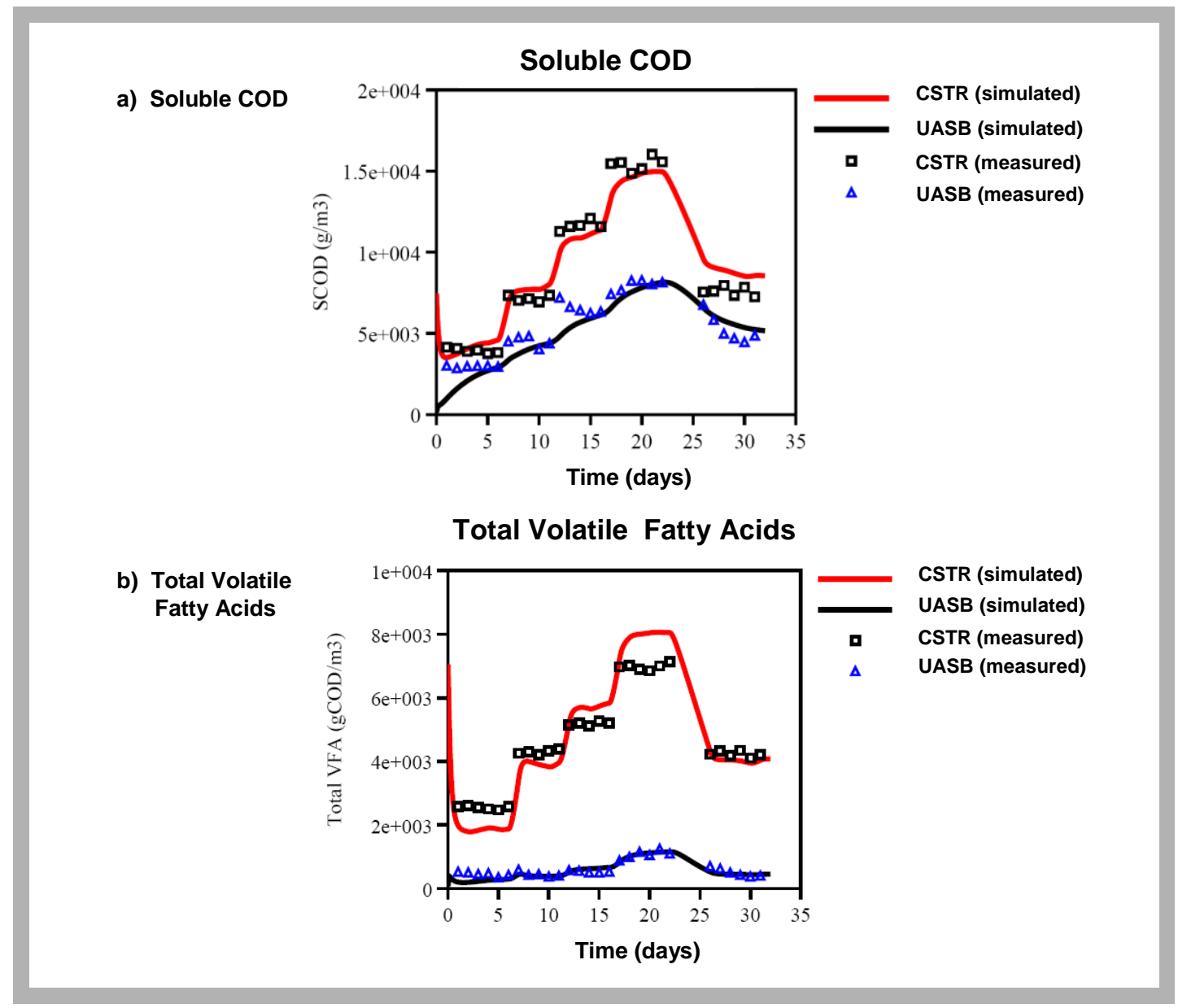

\section{Figure 6}

Validation of simulations with experimental results

a) Soluble COD

b) total VFA

c) sulfate

d) Gas flow rate

e) effluent $\mathrm{pH}$ 
Figure 6

Validation of simulations with experimental results

a) Soluble COD

b) total VFA

c) sulfate

d) Gas flow rate

e) effluent $\mathrm{pH}$ (contd.)

\section{Sulfate}

c) Sulfate

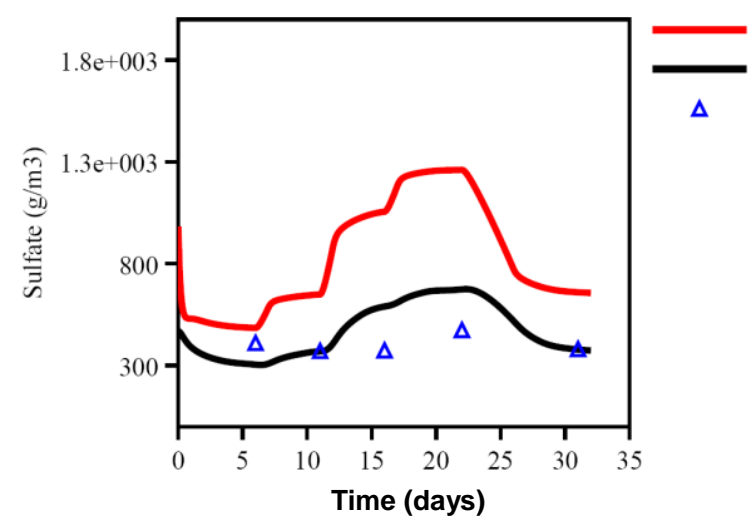

CSTR (simulated)

UASB (simulated)

UASB (measured) d) Gas Flow

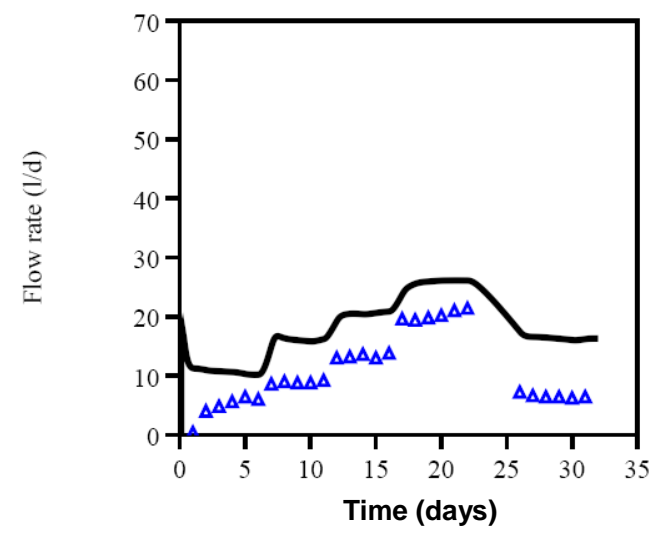

Effluent pH

e) Effluent pH

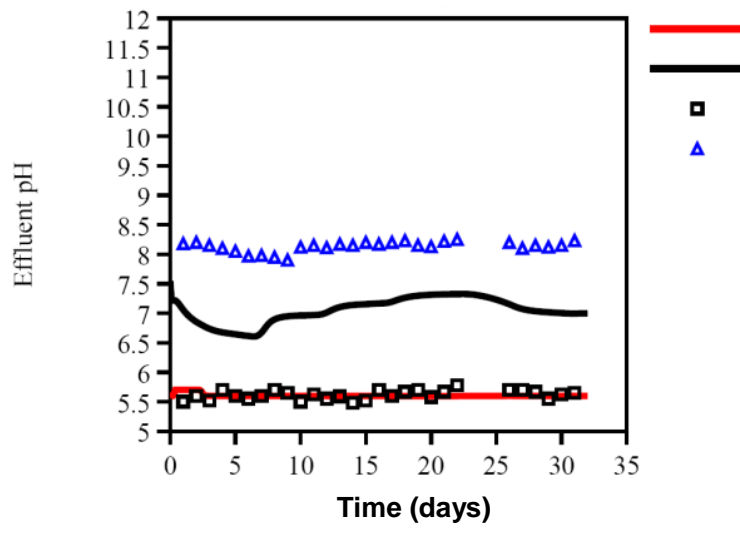

measured

simulated
CSTR (simulated)

UASB (simulated) CSTR (experimental) UASB (experimental)

\section{Conclusions}

The study results show that the ADM1 was successfully implemented to simulate the dynamic behaviour of two-stage anaerobic process treating wastewater generated from molasses-based ethanol distillery process. It can be concluded from the simulation results that the model could accurately predict soluble $\mathrm{COD}$ and $\mathrm{pH}$ in CSTR reactor, but overpredicted total VFA at high organic loading. For UASB reactor, the model could accurately predict soluble COD, total VFA and sulfate in the effluent but underpredicted effluent $\mathrm{pH}$ and gas flow rate. Therefore, it can be concluded that the fundamentals of the model are generally valid and sufficient for the application in the design and operation of the full-scale system under various operating conditions. However, further studies are required to improve the model performance on the prediction of gas flow rate, and $\mathrm{pH}$. 


\section{REFERENCES}

[1] D. J. Batstone, et al., Anaerobic Digestion Model No.1 (ADM1), IWA Task Group for Mathematical Modelling of Anaerobic Digestion Processes, Scientific and Technical Report No. 13, London: IWA Publishing, 2002.

[2] D. J. Batstone, et al., "The IWA anaerobic digestion model No. 1 (ADM1) " Water Science and Technology, vol. 45, no. 10, pp. 65-73, 2002.

[3] Y. Feng, J. Behrendt, C. Wendland, and R. Otterpohl, "Implementation of the IWA anaerobic digestion model No.1 (ADM1) for simulating digestion of blackwater from vacuum toilets," Water Science and Technology, vol. 53, no. 9, pp. 253-263, 2006.

[4] F. Boubaker and B. C. Ridha, "Modelling of the mesophilic anaerobic co-digestion of olive mill wastewater with olive mill solid waste using anaerobic digestion model no.1 (ADM1)," Bioresource Technology, vol. 99, no. 14, pp. 6565-6577, 2008.

[5] Z. Chen, D. HU, Z. Zhang, N. Ren, and H. Zhu, "Modelling of two- phase anaerobic process treating traditional chinese medicine wastewater with the IWA anaerobic digestion model no.1," Bioresource Technology, vol. 100, no. 20, pp. 4623-4631, 2009.

[6] F. Silva, H. Nadais, A. Prates, L. Arroja, and I. Capela,"Modelling of anaerobic treatment of evaporator condensate (EC) form a sulphite pulp mill using the IWA anaerobic digestion model no.1 (ADM1)," Chemical Engineering Journal, vol. 148, no. 2-3, pp. 319- 326, 2009.

[7] K. Derbal, M. Bencheikh-lehocine, F. Cecchi, A. H. Meniai, and P. Pavan, "Application of the IWA ADM1 model to simulate anaerobic co-digestion of organic waste with activated sludge in mesophilic condition," Bioresource Technology, vol.100, no. 4, pp.1539-1543. 2009.

[8] D. J. Batstone, "Mathematical modelling of anaerobic reactors treating domestic wastewater : Rational criteria for model use," Reviews Environmental Science and Biotechnology, vol. 5, no. 1, pp. 57-71, 2006.

[9] V. Fedorovich, P. Lens, and S. Kalyuzhnyi, "Extension of anaerobic digestion model No.1 with processes of sulfate reduction," Applied Biochemistry and Biotechnology, vol. 109, no. 1-3, pp. 33-45, 2003.

[10] N. E. Ristow and G. S. Hansford,"Modelling of a falling sludge bed reactor using AQUASIM," Water SA, vol. 27, no. 4, pp. 445-454, 2001.

[11] P. Reichert, "AQUASIM - A Tool for simulation and data analysis of aquatic systems," Water Science and Technology, vol. 30, no. 2, pp. 21-30, 1994.

[12] P. Reichert, R. V. Schulthess, and D. Wild, "The use of AQUASIM for estimating parameters of activated sludge models," Water Science and Technology, vol. 31, no. 2, pp. 135-147, 1995.

[13] P. Reichert, AQUASIM 2.0-User Manual, Computer Program for the Identification and Simulation of Aquatic System, (EAWAG), Switzerland, 1998. 